\title{
The Role of Thiol-Disulfide and Ischemia-Modified Albumin in The Differential Diagnosis of Acute Scrotum in Children
}

\author{
Çocuklarda Akut Skrotumun Ayırıcı Tanısında Tiyol-Disülfid ve İskemi Modifiye \\ Albüminin Rolü
}

\author{
Can İhsan Öztorun1, @Rabia Demir Ata 2, Gökhan Demirtaş3, @Süleyman Arif Bostanc133,

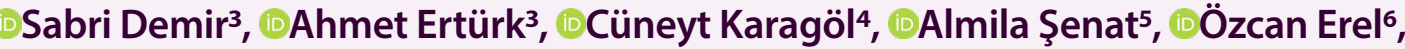 \\ (D)Doğuş Güney33, @Müjdem Nur Azılı', @Emrah Şenel'1
}

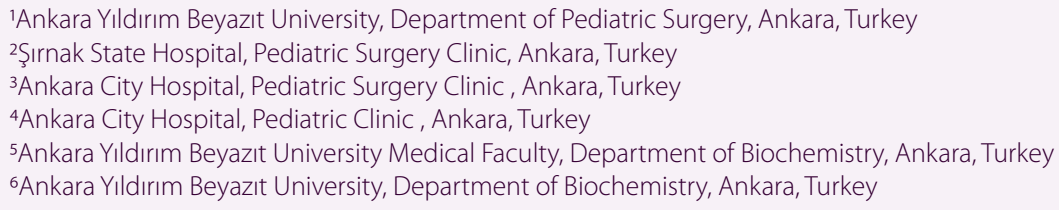

\section{ABSTRACT}

\begin{abstract}
Aim: Testicular torsion, which is among the most common causes of acute scrotum, is a true surgical emergency. However, despite advanced imaging techniques and laboratory tests, the differential diagnosis from other pathologies causing acute scrotum is difficult. Therefore, more specific laboratory tests are needed to confirm the diagnosis. We aimed to investigate the usability of a laboratory test in the differential diagnosis of acute scrotum in children by measuring thiol-disulfide and ischemia modified albumin (IMA) levels.
\end{abstract}

Material and Method: Of 60 male children, 30 with acute scrotum and 30 healthy boys who were admitted for circumcision were included. The levels of native thiol (SH), total thiol $(\mathrm{SH}+\mathrm{SS})$, dynamic disulfide $(\mathrm{SS}), \mathrm{SS} / \mathrm{SH}+\mathrm{SS}$ percentage rate, albumin and IMA were measured. Patients' pre-operative and postoperative first-day blood test results were compared.

Results: The SH $(p=0.025), S H+S S(p=0.032)$, SS $(p=0.045)$, albumin $(p<0.001)$ and IMA $(p<0.001)$ levels of the acute scrotum group were significantly higher than those of the control group. The IMA levels of the epididymo-orchitis subgroup of acute scrotum were found to be higher than those of the testicular torsion subgroup. Pre- and post-operative results of the acute scrotum group were similar for all variables ( $p>0.05$ ).

Conclusion: The evaluation of thiol-disulfide homeostasis and IMA levels and the detection of changes in favour of oxidative stress might help in the differential diagnosis of acute scrotum, but those results cannot help differentiate testicular torsion from an epididymo-orchitis diagnosis.

Keywords: Acute scrotum, children, IMA, thiol-disulfide

\section{ÖZ}

Amaç: Akut skrotumun en sık nedenleri arasında yer alan testis torsiyonu, gerçek bir cerrahi acildir. Ancak ileri görüntüleme teknikleri ve laboratuvar tetkiklerine rağmen akut skrotuma neden olan diğer patolojilerden ayırt edilmesi zordur. Bu nedenle, tanıyı doğrulamak için daha spesifik laboratuvar testlerine intiyaç vardır. Çalışmada, tiyol-disülfid ve iskemi modifiye albümin (IMA) düzeylerini ölçerek çocuklarda akut skrotumun ayırıcı tanısında bir laboratuvar testinin kullanılabilirliğini araştırmayı amaçladık.

Gereç ve Yöntem: 30'u akut skrotumlu ve 30 sünnet için başvuran sağlıklı erkek çocuk olamk üzere 60 erkek çocuk çalışmaya dahil edildi. Native tiyol (SH), total tiyol (SH+SS), dinamik disülfid (SS), SS/ SH+SS yüzde oranı, albümin ve IMA seviyeleri ölçüldü. Hastaların ameliyat öncesi ve ameliyat sonrası ilk gün kan testi sonuçları karşılaştırıldı.

Bulgular: Akut skrotum grubunda SH $(p=0,025), S H+S S(p=0,032)$, SS $(p=0,045)$, albümin $(p<0,001)$ ve IMA $(p<0,001)$ düzeyleri, anlamlı olarak kontrol grubundan daha yüksek bulundu. Akut skrotumun epididimo-orşit alt grubunun IMA düzeyleri testis torsiyonu alt grubuna göre daha yüksek bulundu. Akut skrotum grubunun ameliyat öncesi ve sonrası sonuçlarında anlamlı farklılık yoktu $(p>0.05)$

Sonuç:Tiyol-disülfid dengesi ve IMA düzeylerinin değerlendirilmesi sonucu oksidatif stres lehine değişikliklerin saptanması akut skrotumun ayııcı tanısında yardımcı olabilir, ancak bu sonuçlar testis torsiyonunu epididimo-orşit tanısından ayırmaya yardımcı olamaz.

Anahtar Kelimeler: Akut skrotum, çocuklar, IMA, tiyol-disülfid 


\section{INTRODUCTION}

Acute scrotum is a pathology that presents itself in the inguinoscrotal region with sudden pain, swelling and redness due to various aetiological reasons. ${ }^{[1,2]}$ The most common cause of acute scrotum is testicular torsion. ${ }^{[3]}$ Testicular torsion is a true surgical emergency because the longer the testis remains torsed, the less the chance of recovery. ${ }^{[3]}$ While advanced imaging techniques and laboratory studies are used in the differential diagnosis of pathologies causing acute scrotum, it is not always easy to confirm this diagnosis. ${ }^{[4]}$ Surgical exploration of acute scrotum (as a treatment) ensures that testicular torsion is not overlooked; however, it is still controversial due to some considering it an unnecessary surgical intervention. ${ }^{[5]}$ Therefore, there is a need for laboratory parameters that confirm the diagnosis of testicular torsion.

In inflammatory events, the activation of neutrophils and macrophages and excessive production of reactive oxygen species (ROS) increase oxidative stress (OS). ${ }^{[6-8]}$ Damage due to ROS is prevented by enzymatic or nonenzymatic antioxidant mechanisms, including super-oxide dismutase, catalase and glutathione S-trans enzyme systems and important biological thiols, such as glutathione, cysteine, homocysteine, $\mathrm{N}$-acetyl cysteine and gamma glutamine. Thiol is an organic compound that contains a -SH group, which plays a critical role in the prevention of OS in cells. SH-containing amino acid groups in proteins are primary targets of ROS. ${ }^{[9]}$

In the same medium with ROS, the -SH groups are oxidised and form reversible disulfide bonds. Loss of thiol groups is the main molecular mechanism that results in structural and functional changes in proteins. Antioxidants, especially thiol groups that try to prevent the destructive effects of free radicals, cannot maintain plasma and tissue levels during these interactions. ${ }^{[10]}$ However, the formed disulfide bonds can be reduced to thiol groups by the cellular reduction effects of some antioxidants; thus, thiol-disulfide homeostasis is preserved. ${ }^{[11]}$

The ischemia modified albumin (IMA) test is an FDAapproved test among newly investigated cardiac markers. ${ }^{[12]}$ The principle of the test is based on measuring the cobalt-binding capacity of albumin, leading to chemical changes in the albumin during ischemia. This new albumin molecule is also called IMA. The formation of this new albumin molecule, which has lost its ability to bind cobalt, is one of the earliest markers of ischemia. ${ }^{[13]}$ However, recent studies suggest that IMA, which stands out as a marker of cardiac ischemia, might very well increase in different pathologies. ${ }^{[14-16]}$

Our study aimed to investigate the usability of the diagnostic as a laboratory parameter in the differential diagnosis of acute scrotum causing inflammation in children via thiol-disulfide and IMA levels.

\section{MATERIAL AND METHOD}

In this study, a total of 60 male children, including 30 boys who were admitted to the paediatric surgery clinic due to acute scrotum (patient group) and 30 healthy boys who were admitted for circumcision (control group), were included. Acute scrotum was diagnosed with physical examination and absence of blood flow of testis on the scrotal doppler ultrasonography. The study was conducted prospectively in our hospital between $1^{\text {st }}$ April 2017 and $1^{\text {st }}$ April 2018. Study permission was obtained from the ethics committee of the Ankara Children's Hematology Oncology Education and Training Hospital (decision no. 2017/03 dated 27/03/2017). Informed consent forms were obtained from the parents of the patients and controls included in this study.

The thiol-disulfide and IMA levels of the patients who were operated on for acute scrotum were compared with those of the control group. Thirty boys who were operated for acute scrotum were were divided into two sub-groups as testicular torsion or epididymorochitis by diagnosed at surgery. The thiol-disulfide and IMA levels were compared between those groups too. The patients' blood samples were taken in the pre-operative period and on the first post-operative day. Two $\mathrm{ml}$ of blood were taken from the cases and placed in yellow cap gel tubes (BD Vacutainer plastic SST II tube ${ }^{\circledast}$ ). Blood samples were collected after centrifuging at 3,600 rpm for 10 minutes, and $2 \mathrm{ccs}$ of serum were obtained and stored at $-80^{\circ} \mathrm{C}$ in the biochemistry laboratory. After all the samples were collected, they were thawed at the same time, and the blood thiol-disulfide parameters were determined by Erel and Neselioglu's newly developed automatic measurement method. ${ }^{[17]}$ The IMA levels were studied in a Roche Hitachi Cobas C501 automatic analyser with the colorimetric method, as described by Bar-Or et al. ${ }^{[18]}$ at Ankara Ataturk Training and Research Hospital's biochemistry laboratory.

The levels of $\mathrm{SH}, \mathrm{SH}+\mathrm{SS}, \mathrm{SS}, \mathrm{SS} / \mathrm{SH}+\mathrm{SS}$, albumin and IMA were measured from the sera of patients and controls. These results of patients and control grups were examined by comparing the differences.

\section{Statistical Analyses}

Statistical analysis was performed using the Statistical Package for the Social Sciences (SPSS) 17.0 (Chicago Inc., 2008) programme. Continuous variables' normal distribution was checked with the Shapiro-Wilk test. While the $\mathrm{SH}+\mathrm{SS}$ and albumin levels of the two groups were found to have normal distribution, the IMA, SH, $\mathrm{SS}$ and $\mathrm{SS} / \mathrm{SS}+\mathrm{SH}$ ratio values did not. For the normally distributed variables, the mean values of the variables were analysed using the Student's t test and ANOVA testing. Other variables were analysed using the MannWhitney $\mathrm{U}$ test and Kruska-Wallis $\mathrm{H}$ Test, with $\mathrm{p}<0.05$ considered significant. 


\section{RESULTS}

\section{Demographics data}

The mean age of the patients in the acute scrotum group was 12.12 years (standard deviation $=4.63$, range: 0.2-18 years), and the control group was 7.6 years (standard deviation $=2.54$, range: $3-13$ years). There was no statistical difference between the groups. $(p=0,46)$.

\section{Laboratory results}

The $\mathrm{SH}, \mathrm{SH}+\mathrm{SS}, \mathrm{SS}, \mathrm{SS} / \mathrm{SS}+\mathrm{SH}$ percentage ratio, IMA and albumin levels of the acute scrotum and control groups and their statistical analysis are shown in Table 1.

The SH $(p=0.025), S H+S S(p=0.032)$, SS $(p=0.045)$, albumin $(p<0.001)$ and IMA $(p<0.001)$ levels of the acute scrotum group were found to be significantly higher than those of the control group. Although the $\mathrm{SS} / \mathrm{SH}+\mathrm{SS}$ percentage ratio was higher than that of the control group, it was not statistically significant $(p=0.38)$.

Patients in the acute scrotum group were divided into two sub-groups: children with testicular torsion and children with epididymo-orchitis. The two groups were also compared in terms of their $\mathrm{SH}, \mathrm{SH}+\mathrm{SS}, \mathrm{SS}, \mathrm{SS} / \mathrm{SH}+\mathrm{SS}$ percentage ratio, albumin and IMA levels (Table 2 ).

There was no statistically significant difference between the two sub-groups in terms of $\mathrm{SH}, \mathrm{SH}+\mathrm{SS}, \mathrm{SS}, \mathrm{SS} /$ $\mathrm{SH}+\mathrm{SS}$ percentage ratio and albumin levels, whereas the IMA levels of the epididymo-orchitis group were significantly higher than those of the testicular torsion group.

\begin{tabular}{|c|c|c|c|c|c|}
\hline Variables & Groups & $\mathbf{n}$ & Mean & SD & p value \\
\hline \multicolumn{5}{|c|}{ Native thiol (SH) } & $0.025^{*}$ \\
\hline & Acute scrotum & 30 & 421 & 49.41685 & \\
\hline & Control & 30 & 393.723 & 54.74252 & \\
\hline \multicolumn{5}{|c|}{ Total thiol (SH + SS) } & $0.032^{* *}$ \\
\hline & Acute scrotum & 30 & 467.6 & 57.92349 & \\
\hline & Control & 30 & 434.62 & 58.5673 & \\
\hline \multicolumn{5}{|c|}{ Disulfide (SS) } & $0.045^{*}$ \\
\hline & Acute scrotum & 30 & 23.2667 & 6.15284 & \\
\hline & Control & 30 & 20.4333 & 4.27247 & \\
\hline \multicolumn{5}{|c|}{ Disulfide (SS) / Total thiol (SH+SS) \% } & $0.308^{*}$ \\
\hline & Acute scrotum & 30 & 4.9339 & 0.89738 & \\
\hline & Control & 30 & 4.7209 & 0.93069 & \\
\hline \multicolumn{5}{|c|}{ Ischemia-modified Albumin (IMA) } & $0.00^{*}$ \\
\hline & Acute scrotum & 30 & 0.5826 & 0.09985 & \\
\hline & Control & 30 & 0.7003 & 0.14878 & \\
\hline \multirow[t]{3}{*}{ Albumin } & & & & & $0.00 * *$ \\
\hline & Acute scrotum & 30 & 4.76 & 0.26987 & \\
\hline & Control & 30 & 4.41 & 0.32626 & \\
\hline
\end{tabular}

In the acute scrotum group, the pre- and postoperative levels of $\mathrm{SH}, \mathrm{SH}+\mathrm{SS}, \mathrm{SS}, \mathrm{SS} / \mathrm{SH}+\mathrm{SS}$ percentage rate, albumin and IMA were compared with a paired correlation test (see Table 3). All pre- and post-operative variables were similar ( $p>0.05)$.

Table 2. Testicular torsion $(n=16)$ and epididymoorchitis $(n=14)$ ' laboratory findings

\begin{tabular}{|c|c|c|c|c|c|}
\hline Variables & Groups & $\mathbf{n}$ & Mean & SD & p value \\
\hline \multicolumn{5}{|c|}{ Native thiol (SH) } & $0.308^{* *}$ \\
\hline & Testicular torsion & 16 & 429.75 & 40.84354 & \\
\hline & Epididymo-orchitis & 14 & 411 & 57.62666 & \\
\hline \multicolumn{5}{|c|}{ Total thiol $(\mathrm{SH}+\mathrm{SS})$} & $0.417^{*}$ \\
\hline & Testicular torsion & 16 & 475.794 & 46.07285 & \\
\hline & Epididymo-orchitis & 14 & 458.236 & 69.70064 & \\
\hline \multicolumn{5}{|c|}{ Disulfide (SS) } & $0.76^{* *}$ \\
\hline & Testicular torsion & 16 & 22.9375 & 4.50879 & \\
\hline & Epididymo-orchitis & 14 & 23.6429 & 7.79158 & \\
\hline \multicolumn{5}{|c|}{ Disulfide / Total thiol \% } & $0.428^{* *}$ \\
\hline & Testicular torsion & 16 & 4.81 & 0.77489 & \\
\hline & Epididymo-orchitis & 14 & 5.0755 & 1.03107 & \\
\hline \multicolumn{5}{|c|}{ Ischemia-modified Albumin } & $0.014^{* *}$ \\
\hline & Testicular torsion & 16 & 0.5417 & 0.07212 & \\
\hline & Epididymo-orchitis & 14 & 0.6294 & 0.10878 & \\
\hline \multirow[t]{3}{*}{ Albumin } & & & & & $0.093^{*}$ \\
\hline & Testicular torsion & 16 & 4.8375 & 0.26552 & \\
\hline & Epididymo-orchitis & 14 & 4.6714 & 0.25549 & \\
\hline
\end{tabular}

Table 3. Acute scrotum group ( $n=30$ )'s pre- and postoperative laboratory findings

\begin{tabular}{|c|c|c|c|}
\hline Variables & Mean & SD & p value \\
\hline $\begin{array}{l}\text { Native thiol (SH) } \\
\text { (pre-op) }\end{array}$ & 427.25 & 40.66905 & \multirow{2}{*}{0.465} \\
\hline $\begin{array}{l}\text { Native thiol (SH) } \\
\text { (post-op 1st day) }\end{array}$ & 370.84 & 40.38713 & \\
\hline $\begin{array}{l}\text { Total thiol (SH + SS) } \\
\text { (pre-op) }\end{array}$ & 475.58 & 46.42073 & \multirow{2}{*}{0.437} \\
\hline $\begin{array}{l}\text { Total thiol (SH + SS) } \\
\text { (post-op 1st day) }\end{array}$ & 412.59 & 43.70198 & \\
\hline $\begin{array}{l}\text { Disulfide (SS) } \\
\text { (pre-op) }\end{array}$ & 24.2 & 5.0728 & \multirow{2}{*}{0.223} \\
\hline $\begin{array}{l}\text { Disulfide (SS) } \\
\text { (post-op 1st day) }\end{array}$ & 20.9 & 6.15449 & \\
\hline $\begin{array}{l}\text { Disulfide/Total thiol \% } \\
\text { (pre-op) }\end{array}$ & 5.0734 & 0,84905 & \multirow{2}{*}{0.059} \\
\hline $\begin{array}{l}\text { Disulfide/Total thiol \% } \\
\text { (post-op 1st day) }\end{array}$ & 5.0717 & 1,51395 & \\
\hline $\begin{array}{l}\text { Ischemia-modified Albumin } \\
\text { (pre-op) }\end{array}$ & 0.545 & 0.06173 & \multirow{2}{*}{0.665} \\
\hline $\begin{array}{l}\text { Ischemia-modified Albumin } \\
\text { (post-op 1st day) }\end{array}$ & 0.6024 & 0.06547 & \\
\hline $\begin{array}{l}\text { Albumin } \\
\text { (pre-op) }\end{array}$ & 4.89 & 0.2079 & \multirow{2}{*}{0.606} \\
\hline $\begin{array}{l}\text { Albumin } \\
\text { (post-op 1st day) }\end{array}$ & 4.46 & 0.21187 & \\
\hline
\end{tabular}


Sixteen patients with testicular torsion were evaluated in terms of the time period between the onset of symptoms and their admission to the emergency department. The cases were divided into three groups (Group 1:0-6 hours; Group 2: 7-24 hours; Group 3: more than 24 hours) and evaluated for statistical differences in their laboratory findings. There was no difference between the three groups in terms of their $\mathrm{SH}(\mathrm{p}=0.890), \mathrm{SH}+\mathrm{SS}(\mathrm{p}=0.894)$, SS $(p=0.987), S S / S H+S S$ percentage ratio $(p=0.940)$, albumin $(p=0.776)$ and IMA ( $p=0.293$ ) levels (one-way ANOVA test).

\section{DISCUSSION}

Testicular torsion, which is among the most common causes of acute scrotum, is a surgical disease affecting newborns, children and adolescents. Twisting of the torsion of the spermatic cord around the longitudinal axis might result in venous congestion, oedema and arterial occlusion, and if left untreated, gonadal necrosis may develop. ${ }^{[19]}$ The longer the testicle remains torsed, the more the testicular tissues remain ischemic, which can result in necrosis formation, making testicular torsion a true surgical emergency. ${ }^{[4]}$ Despite the advanced imaging techniques and laboratory studies currently used in the differential diagnosis of pathologies causing acute scrotum, there are no biochemical markers to demonstrate testicular torsion.

The state of dynamic thiol-disulfide balance plays a critical role in antioxidant protection, detoxification, signal transduction and apoptosis in the regulation of enzymatic activity, transcription factors and cellular signalling mechanisms. ${ }^{[20]}$ In addition, distortions in the dynamic thiol-disulfide balance have been shown to play a role in the pathogenesis of many diseases, such as diabetes, cardiovascular diseases, cancer, rheumatoid arthritis, chronic kidney disease, AIDS, Parkinson's disease, Alzheimer's disease, Friedrich ataxia, multiple sclerosis, amyotrophic lateral sclerosis and liver diseases. [21] Therefore, the determination of the dynamic thioldisulfide balance might provide valuable information regarding various normal or abnormal biochemical processes. ${ }^{[21]}$ Several studies have shown the predictive value of thiol-disulfide haemostasis in organ ischemia. The measurement of plasma or serum thiol-disulfide balance via the colorimetric method was developed by a Turkish scientist. ${ }^{[21]}$

There are many studies on OS markers and their relationship with various diseases, such as acute appendicitis, in children, ${ }^{[22-24]}$ yet no studies exist on the relationship between acute scrotum and OS markers in children. Additionally, many studies have explored the relationship between thiol-disulfide and testis torsion; however, our study is important as the first to show thioldisulfide and IMA levels in the differential diagnosis of acute scrotum in children.
A rat model experimental study by Menteşe et al. showed that thiol-disulfide haemostasis might be a haematologic parameter in the prognosis of early testicular ischaemia, revealing a positive correlation between the decrease in $\mathrm{SH}+\mathrm{SS}$ values and histopathologic injury in the testis following ischaemia-reperfusion. ${ }^{[25]}$ Their study also showed that ischaemia-modified albumin could be predictive of testicular injury in short- (2 hr) and longterm ( 2 months) testicular torsion, which could be a marker for fertility capacity. ${ }^{[25]}$

In our study, the SH+SS/SS homeostasis markers' of the $\mathrm{SH}+\mathrm{SS}, \mathrm{SH}$ and SS levels of the patients in the acute scrotum group were significantly increased compared to those of the control group, except for the $\mathrm{SS} / \mathrm{SH}+\mathrm{SS}$ percentage rate, which was similar to that of the control group. The IMA and albumin levels also increased statistically.

There was no difference between the two sub-groups of acute scrotum regarding their $\mathrm{SH}+\mathrm{SS}, \mathrm{SH}, \mathrm{SS}, \mathrm{SS} /$ $\mathrm{SH}+\mathrm{SS}$ percentage ratio, albumin and IMA levels. These results indicate that in the acute scrotum group, OS shifted towards the oxidant side; hence, there was an OS increase. However, there was no difference in the levels of thiol-disulfide balance and IMA when the testicular torsion and epididymo-orchitis cases were compared. Therefore, thiol-disulfide balance and IMA levels cannot be used as markers for the differentiation of testis torsion and epididymo-orchitis, which are the most common causes of acute scrotum in children. There was no statistical difference in the $\mathrm{SH}+\mathrm{SS}, \mathrm{SH}, \mathrm{SS}, \mathrm{SS} / \mathrm{SH}+\mathrm{SS}$ percentage ratio, albumin and IMA levels in the acute scrotum cases' pre- and postoperative blood samples. These results indicate that the thiol-disulfide balance in the acute scrotum cases shifted towards the oxidative side, resulting in increased OS levels.

\section{CONCLUSION}

The development of a specific test in the differential diagnosis of acute scrotum in children would assist with early diagnosis and thus early surgery in testicular torsion as well as prevent unnecessary surgical interventions. Physical examination of findings, imaging methods and current laboratory tests, along with the evaluation of thiol-disulfide homeostasis and IMA levels and the detection of changes in favour of OS, might help in the differential diagnosis of acute scrotum. However, these results cannot help to distinguish testicular torsion from an epididymo-orchitis.

\section{ETHICAL DECLARATIONS}

Ethics Committee Approval: Study permission was obtained from the ethics committee of the Ankara Children's Hematology Oncology Education and Training Hospital (decision no. 2017/03 dated 27/03/2017). 
Informed Consent: Informed consent forms were obtained from the parents of the patients and controls included in this study.

Referee Evaluation Process: Externally peer-reviewed.

Conflict of Interest Statement: The authors have no conflicts of interest to declare.

Financial Disclosure: The authors declared that this study has received no financial support.

Author Contributions: All of the authors declare that they have all participated in the design, execution, and analysis of the paper, and that they have approved the final version.

\section{REFERENCES}

1. Ciftci $A O$, Senocak ME, Tanyel FC et al. Clinical predictors for differential diagnosis of acute scrotum. Eur J Pediatr Surg 2004; $14: 333-8$

2. Mushtaq I, Fung M, Glasson MJ. Retrospective review of paediatric patients with acute scrotum. ANZ J Surg 2003;73:55-8.

3. Colodny AH. Acute urologic conditions. Pediatr Ann 1994;23:20710.

4. Rabinowitz R, Hulbert WC. Acute scrotal swelling. Urol Clin North Am 1995;22:101-5.

5. Çaman Ş, İnanç C, Pelin A, et al. Akut Skrotum;Çocuk Ürolojisinin Onemli Bir Acil Durumu. Zeynep Kamil Tıp Bülteni 2014:45:49-53.

6. Bolukbas C, Bolukbas FF, Horoz M, et al. Increased oxidative stress associated with the severity of the liverdisease in various forms of hepatitis B virus infection. BMC Infect Dis 2005;31:5-95.

7. Ozdogan M, Devay $\mathrm{AO}$, Gurer A, et al.Plasma total antioxidant capacity correlates inversely with the extent of acute appendicitis:a case control study. World J Emerg Surg 2006;24:1-6.

8. Serefhanoglu K, Taskin A, Turan H, Ergin Timurkaynak F, Arslan H, Erel Ö. Evaluation of oxidative status in patients with brucellosis. Braz J Infect Dis 2009;13:249-51.

9. 9.Valko M, Leibfritz D, Moncol J et al. Free radicals and antioxidants in normal physiological functions and human disease. Int Biochem Cell Biol 2007; 39:44-84.

10. McCord JM. Human disease, free radicals, and the oxidant/ antioxidant balance. Clin Biochem 1993;26:1-7.

11. Kundi $\mathrm{H}$, Ates I, Kiziltunc $\mathrm{E}$ et al. A novel oxidative stress marker in acute myocardial infarction;thiol/disulphide homeostasis. Am J Emerg Med 2015;33:1567-71.

12. Wudkowska A, Goch J, Goch A. Ischemia-modified albumin in differential diagnosis of acute coronary syndrome without ST elevation and unstable angına pectoris. Kardiologia Polska 2010;68:431-7.

13. Aran T, Unsal MA, Güven S, Kart C, Can Cetin E, Alver A. Carbon dioxide Pneumoperitoneum Induces Systemic Oxidative Stres:a clinical study. Eur J Obstet Gynecol Reprod Biol 2012;161:80-3.

14. Ma SG, Wei $C L$, Hong $B$, Yu W. Ischemia-modified albumin in type 2 diabetic patients with and without peripheral arterial disease. Clinics 2011;66:1677-80.

15. Mastella AK, Moresco RN, da Silva DB, et al. Evaluation of ischemia modified albumin in myocardial infarction and prostatic diseases. Biomed Pharmacother 2009;63.762-6.

16. Lippi G, Montagnana M. Ischemia Modified Albumin in Ischemic Disorders. Ann Thorac Cardiovasc Surg 2009;15(2):137

17. Erel O. Neselioglu S. A novel and automated assay for thiol/ disulfide homeostasis. Clin Biochem 2014;47(18):326-32

18. Bar-Or D, Lau E, Winkler JV. A novel assay for cobalt-albumin binding and its potential as a marker for myocardial ischemia a preliminary report. J Emerg Med 2000;19.311-5.

19. Cattolica EV, Karol JB, Rankin KN et al. High testicular salvage rate in torsion of the spermatic cord. J Urol 1982;128(1):66-8.

20. Circu ML, AwTY. Reactive oxygenspecies, cellular redox systems, andapoptosis. Free Radic Biol Med 2010;48(6):749-62.

21. Ozcan Erel, Salim Neselioglu. A novel and automated assay for thiol/disulphide homeostasis. Clin Biochem 2014;47:326-32.
22. Uğur $\mathrm{C}$, Madenci $\mathrm{H}$, Kurku $\mathrm{H}$. et al. The Use of Thiol/Disulfide Homeostasis Parameters in the Diagnosis of Acute Appendicitis in Children. J Pediatr Infect Dis 2020;15(04):195-9.

23. Demir S, Günal YD, Özmen i et al. Can thiol/disulphide homeostasis help in the differential diagnosis of appendicitis in children?. Türkiye Çocuk Hastalıkları Derg 2020;1-8.

24. Ertürk A, Öztorun C, Bostancı SA. et al. The role of thiol-disulfide and ischemia-modified albumin levels in the diagnosis of childhood appendicitis. Anatolian Curr Med J 2021;3(3):214-9.

25. 25.Urkmez A, Kutluhan MA, Topaktaş R et al. "Prognostic value of thiol/disulphide homeostasis in predicting testicular ischaemiareperfusion injury in rats." Andrologia 2018;50:e13134.

26. 26. Mentese, A, Turkmen, S, Karaguzel, E. et al. The predictive value of ischemia-modified albumin in long-term results of ischemia-reperfusion injury in an experimental testicular torsion model. Urology 2012;80(3):689-94. 